\title{
Аналіз факторів впливу на систему ресурсного забезпечення сектору безпеки і оборони України
}

\author{
Анатолій Лойшин * 1 А \\ А Головна інспекція Міністерства оборони України, м. Київ, Україна
}

Received: November 5, 2021 | Revised: December 10, 2021 | Accepted: December 30, 2021

DOI: $10.33445 /$ sds.2021.11.6.6

\begin{abstract}
Анотація
У даній статті розглядається проблема ідентифікації факторів впливу на систему ресурсного забезпечення сектору безпеки і оборони України. Обґрунтовується погляд що ідентифікація як найбільшої кількості факторів дасть, у подальшому, змогу чітко визначити межі дослідження та предмет дослідження. Прослідковується тенденція до підвищеної уваги до розроблення нової концепції ресурсного забезпечення сектору безпеки і оборони України серед науковців. Метою статті $\epsilon$ ідентифікація факторів зовнішнього та внутрішнього впливу на систему ресурсного забезпечення сектору безпеки і оборони України для подальшого їх аналізу при розробленні сучасної концепції ресурсного забезпечення сектору безпеки і оборони України. Автор приходить до висновку, що сфера сучасних трансформацій у сфері безпеки і оборони вимагає перегляду існуючих механізмів ресурсного забезпечення потреб оборони. Особлива увага у статті приділена аналізу існуючих наукових поглядів щодо проблематики предметної системи. Автором запропонована систематизація ідентифікованих факторів впливу на систему ресурсного забезпечення сектору безпеки оборони через призму складових PEST-аналізу, а саме за напрямом, політичних, економічних, соціально-культурних та технологічних факторів. Враховуючі специфіку військової справи до переліку складових РEST-аналізу пропонується ввести п'яту складову - специфічні фактори. Загалом протягом дослідження виділено 82 фактори зовнішнього та внутрішнього впливу на предметну систему. На основі проведеного аналізу, ідентифікації та систематизації факторів впливу встановлена необхідність їх подальшого оцінювання та ранжування для визначення пріоритетності факторів та їх ваги. Результати дослідження можуть бути корисними для науковців та управлінців, які обіймаються питаннями (проблематикою) ресурсного забезпечення сектору безпеки і оборони України.
\end{abstract}

Ключові слова: ресурсне забезпечення, фактори впливу, сектор безпеки і оборони.

\section{Постановка проблеми}

Станом на сьогодні, сектор безпеки і оборони України (СБ і О України) перебуває на стадії трансформації, що $є$ обґрунтованою необхідністю відповідно до взятого Україною курсу щодо інтеграції у європейський простір та набуття членства в НАТО. Приєднання до Північно-атлантичного альянсу відкриває нові можливості у підвищенні рівня національної безпеки, де напад на Україну означатиме напад на всіх членів НАТО.

Відповідно до зазначеного, концептуальними документами з розвитку та удосконалення СБіО України та його складових, оборонного планування визначено низку пріоритетних цілей щодо подальшого розвитку та набуття спроможностей що дозволять гідно відповісти агресору у разі ескалації збройної боротьби на території України.

Розбудова сучасних Збройних Сил України (3С України) та інших складових сектору безпеки і оборони України потребує

\footnotetext{
1 * Corresponding author: доктор філософії, старший інспектор Головної інспекції, e-mail: aloishyn@gmail.com, ORCID: 0000-0003-2769-9336
} 
удосконалення існуючих механізмів ресурсного забезпечення потреб оборони.

Так, відповідно до Стратегії національної безпеки України [1] існують проблеми у сфері переозброєння ЗС сучасним озброєнням; наявний дефіцит фінансових ресурсів гальмує своєчасне та повне забезпечення новітніми зразками озброєння та військової техніки (ОВТ); визначена необхідність посилення оборонних і безпекових спроможностей Збройних Сил України та інших органів сектору безпеки і оборони.

Відповідно до Стратегії воєнної безпеки України запроваджується підхід, що ґрунтується на всеохоплюючій обороні, яку буде побудовано на засадах стримування та стійкості. Одними з ключових цілей Стратегії воєнної безпеки України є:

- ефективний менеджмент у сфері оборони, заснований на засадах демократичного цивільного контролю, інших євроатлантичних принципах і стандартах, інноваційних рішеннях та сучасних бізнеспрактиках, програмно-проектному управлінні оборонними ресурсами, удосконалених процесах визначення та задоволення потреб оборони України;

- упровадження програмно-проектного управління оборонними ресурсами 3 розробленням та своєчасним оновленням комплексу програм і проектів розвитку оборонних спроможностей, планів утримання і розвитку відповідних складових сил оборони, забезпечення виконання державних цільових програм [2].

Усе вище викладене, безумовно, потребує не лише збільшення видатків на оборону України, а й удосконалення механізмів повного (за пріоритетом), своєчасного та ефективного забезпечення необхідними ресурсами.

\section{Аналіз останніх досліджень та публікацій}

Аналіз останніх досліджень та публікацій показав наявність чималої кількості наукових публікацій та інших джерел у сфері забезпечення потреб оборони.

Так, проблематиці у сфері ресурсного забезпечення СБіО України (СРЗ СБ іО України) присвячено праці: Р. Бойка, М. Бутенка, В. Гудима, М. Дєнежкіна, П. Жупінського, А. Фатальчука М. Петрушена, С. Полторака, В. Сисоєва, А. Наливайка, П. Крикуна, А. Поляєва, О. Суркова, В. Замани та Постановка завдання

Метою статті є ідентифікація факторів впливу на СБ і О України для подальшого їх аналізу у ході розроблення сучасної концепції ресурсного забезпечення СБ і О України.

Для досягнення мети дослідження було

\section{Виклад основного матеріалу}

У 1856 році відомий військовий публіцист А. І. Астаф’ $є$ у у своїй праці “Про сучасне військове мистецтво” [12] піддав сумніву метафізичне вчення військового теоретика Г. iн. [3-11].

Водночас, питання ідентифікації та систематизації факторів внутрішнього та зовнішнього впливу на СБіО України в умовах ведення гібридної війни з боку східного сусіда та науково-технічного прогресу $є$ недостатньо дослідженим.

Це також підтверджується попередньо проведеним автором контент-аналізу сфери ресурсного забезпечення [52].

проведено аналіз наукових джерел на предмет ідентифікації факторів впливу на систему ресурсного забезпечення СБіО України. У ході дослідження використано такі методи теоретичного дослідження: аналіз, синтез, історичний метод.

Жоміні щодо вічності принципів військового мистецтва. Науковець прийшов до висновку, що керівництво військовими діями повинно бути засноване не на врахуванні одного-двох 
факторів, а на основі усіх факторів впливу, що мають вплив на війну.

Тому, при дослідженні факторів впливу на СРЗ СБ іО України виникає необхідність у проведенні ідентифікації як найбільшої кількості факторів відповідного впливу 3 послідуючим оцінюванням кожного з них.

Широкий спектр ідентифікованих факторів у подальшому, дасть змогу якісно провести ідентифікацію факторів впливу з найвищим рівнем пріоритету.

Для послідовності викладення інформації пропонується, перш за все, розглянути зміст термінів: “фактор", “фактор внутрішнього впливу”, “фактор зовнішнього впливу”.

В Академічному тлумачному словнику української мови [13], “фактор - умова, рушійна сила будь-якого процесу, явища; чинник".

У словнику по технічному регулюванню під зовнішнім фактором впливу розуміється: “явище, процес або середовище, зовнішніми по відношенню до виробу або його складових частин, що характеризуються фізичними величинами, які викликають, або можуть викликати обмеження або втрату працездатного стану виробу або перехід його в граничний стан в процесі експлуатації" [14].

На нашу думку, більш повно формулюється зміст факторів внутрішнього та зовнішнього впливу визначений О. О. Дюбановим: “до зовнішніх належать фактори, які діють поза об'єктом дослідження, мають на нього суттєвий вплив, але, зазвичай, не підлягають управлінню. Такі фактори можуть бути лише враховані. До внутрішніх належать фактори, які діють усередині об'єкту, що досліджується, визначають його стан та піддаються цілеспрямованому впливу (управлінню)" [15].

Дослідження проведено шляхом аналізу наукових джерел, що $є$ у вільному доступі, для ідентифікації факторів впливу на СРЗ СБ і О України. Аналізом виділено такі сфери ідентифікації та подальшої структуризації факторів: політична, економічна, соціальнокультурна, специфічна, технологічна.

Далі, детально розглянемо думки окремих науковців та окремих наукових положень різних періодів дослідження воєнної науки щодо ідентифікації (формулювання) факторів впливу.

У XVIII ст. велика увага приділялась діяльності військового керівництва відповідно до чого, одним з основних факторів впливу на ведення війни, вважався геній полководця. Інтерпретуючи означене із сьогоденням, можна погодитись, що прийняті управлінські рішення 3 питань ресурсного забезпечення СБіО України, насамперед, залежать від професійної компетенції та розумових здібностей тих, хто їх ухвалює. Це дозволяє виділити особистісні здібності лідерів (керівників) як важливий фактор впливу на предметну систему.

Аналіз наукової праці щодо формування військово-теоретичної думки у період XIX-XX ст. [16] дозволив сформулювати наступні фактори:

1) віддаленість військових запасів від районів зосередження військ (сил) обумовлена тезою щодо необхідності розташування військових запасів поблизу пунктів збору військ до початку зосередження у ході стратегічного розгортання на весь період зосередження;

2) мобільність ресурсів - сформульовано виходячи із тенденцій до підвищення мобільності підрозділів за рахунок розвитку інфраструктури та потужності засобів транспортування військ (сил), поряд 3 необхідністю своєчасного забезпечення військ (сил).

У науковій праці щодо діалектики та воєнної науки С. І. Крупнов [17] звертає увагу на залежність ходу та результату війни від соціально-економічних та політичних умов.

Так, у контексті ресурсного забезпечення можна виділити вплив рівня воєнноекономічного потенціалу країни та її економічних можливостей, тобто здатності держави економічно забезпечувати ведення війни.

Також, С. І. Крупнов зосереджує увагу на підвищенні ролі економічних можливостей держави, саме у період Першої та Другої 
світових воєн, що було підтверджено необхідністю забезпечення військ (сил) складною бойовою технікою.

Зазначене пояснюється тим, що війни XVIII - XIX ст. не потребували такої кількості озброєння та військової техніки виробленої, безпосередньо, у ході війни, як це було у наступному столітті, де 75\% артилерійського озброєння та біля 50\% радянської армії було вироблено у ході війни.

Досвід другої світової війни та повоєнний період показав пряму залежність забезпечення військ (сил) від стану наявних виробничих потужностей та рівня їх розвитку у сфері матеріального забезпечення військ (сил). Думку підтверджує у своєму дослідженням І. А. Смирнов, який вказує на перспективи розвитку речового забезпечення, у тісному взаємозв'язку, насамперед, 3 рівнем розвитку галузей легкої та хімічної промисловості [18].

Також, у ході одночасного дослідження функціонування системи тилового забезпечення напередодні та протягом радянсько-німецької війни, ідентифіковано такі фактори прямого та опосередкованого вплив на систему ресурсного забезпечення: всебічне та безперебійне тилове забезпечення військ; живучість та захищеність об'єктів тилу.

У процесі ідентифікації факторів впливу у предметній сфері, слід звернути увагу на наявність формулювання факторів впливу у працях періоду марксистко-ленінської філософії для проведення відповідної аналогії із сьогоденням. Було проаналізовано праці: C. А. Тюшкевича, Ф. Енгельса, Н. Я. Сушко, Т. Р. Кондраткової, М. С. Шифмана та ін.

У працях С. А. Тюшкевича “Філософія та воєнна теорія" [19] та "Необхідність та випадковість на війні" [20] узагальнюється досягнення воєнної теорії та визначається, що визначальне місце у збройній боротьбі відіграють випадковості, які, за своїм змістом, можуть бути як сприятливі, так і несприятливі. Вчений констатує, що кожна випадковість, поряд із необхідністю, включається в систему факторів збройної боротьби та обумовлює ії хід та результат.

Ф. Енгельс наголошував, що: “ніщо так не залежить від економічних умов, як армія та флот. Озброєння, склад, організація, тактика та стратегія залежать, перш за все, від досягнутого у даний момент ступеню виробництва та від засобів сполучення" [21]. Реалізація погляду Ф. Енгельса, безумовно, залежить від рівня воєнно-економічного потенціалу країни.

у науковій праці щодо методологічних проблем воєнної теорії та практики [22] зазначено, що економічні умови та науковотехнічний прогрес $\epsilon$ джерелами та революцією у військовій справі, які активно проявляють себе лише під впливом політики. Це обумовлено тим, що політика $\epsilon$ визначальним фактором та вирішальною силою у виборі пріоритетів та напрямів подальшого розвитку, тим більше у військовій справі. Завдяки відповідній політиці у військову справу впроваджуються досягнення науки і техніки.

у науковій праці щодо дослідження збройного впливу на економіку радянського вченого М. С. Шифмана [23] зазначається, що усі елементи матеріального забезпечення війни, як явища, знаходяться у взаємозалежності. Це пояснюється послабленням характеристик елементів матеріального забезпечення, у разі значного підриву потенціалу одного 3 елементів. Матеріальне забезпечення під час бойових дій спирається на заздалегідь заготовлені запаси та налагоджені відповідного процесу поточного виробництва засобів збройної боротьби.

Далі, проведено частковий аналіз розвитку воєнної науки у деяких війнах (конфліктах), що мали місце в історії.

Аналіз історичних подій, що мали місце протягом Першої світової війни показав започаткування застосування авіації для нанесення ударів по економічним та військово-промисловим об'єктам. Зазначена 
форма ослаблення воєнно-економічного потенціалу стрімко розвивається досі. Тенденції розвитку засобів збройної боротьби підтверджує важливість фактору впливу, який можна сформулювати, як: цілеспрямований (опосередкований) вплив ворожих сил і засобів як на об'єкти обороннопромислового комплексу, так, і на об'єкти економічного значення та інфраструктури.

До факторів впливу на предметну систему слід віднести діяльність іноземних розвідок з метою здійснення економічного шпигунства. Зазначена теза історично підтверджена наявністю документально засвідчених історичних доказів у період з 1918 року і по сьогодні. Як приклад, протягом Першої світової війни англійське морське міністерство отримувало інформацію про розміри товарообігу ворожих та нейтральних країн; спостерігались активні дії німецької розвідки в електричній, паливній, та промисловій галузях Росії [24]. Питання економічного шпигунство гостро стояло протягом “холодної війни” [25]. Український вчений Г. О. Андрощук провів у 2018 році грунтовне наукове дослідження щодо економічного шпигунства та зробив висновок стосовно стрімкої тенденції до його зростання та агресивності. Науковець, спираючись на дослідження американських аналітиків, підтверджує існування в історії реальних подій та вказує, що: “в $58 \%$ випадках економічне і промислове шпигунство здійснювалось за завданнями зарубіжних компаній, в 22\% - в інтересах іноземних урядів і в 20\% - приватних i державних зарубіжних наукових центрів і лабораторій" [26].

Слід додати, що у своїй науковій праці І. Ж. Жакшиликов розглядає економічний шпіонаж у контексті виду недобросовісної конкуренції [27].

Також, до факторів зовнішнього впливу на етапі формування ресурсної бази, які мають опосередкований вплив на предметну систему у сфері діяльності СБ іО України можна віднести [28]:
1) відсутність інвестицій, що необхідні для розвитку оборонної промисловості;

2) брак впровадження проривних технологій в оборонну сферу;

3) скорочення результативності науководослідних та дослідно-конструкторських робіт внаслідок обмеженого фінансування, скорочення видатків;

4) низький рівень впровадження результатів досліджень та найкращих практик;

5) низький рівень матеріального забезпечення персоналу, задіяного у сфері ресурсного забезпечення.

Колективом українських науковців у 2017 році видано монографію [29] щодо дослідження явища світової гібридної війни, у контексті збройної агресії Російської федерації проти України. У монографії проаналізовані показники втрат України у промислово-інноваційній та наукових сферах, зумовлені російською агресією. Відповідно до наведених у монографії даних, майже третину (27\%) промислового потенціалу Донецької та Луганської областей, вивезено до Російської Федерації, але десять наукових установ, завдяки значним зусиллям було переміщено 3 непідконтрольної території Урядом України. Внаслідок тимчасової анексії Росією АР Крим, Україна втратила частину високотехнологічних підприємств - ФСК “Море ”, завод “Фіолент”, близько 100 інших підприємств, що проводили фундаментальні дослідження. Це лише часткові показники, які відображають реальний стан справ у втраті Україною частки воєнно-економічного, промисловоінноваційного та наукового потенціалу, що безпосередньо вплинуло на функціонування системи ресурсного забезпечення сектору безпеки і оборони.

3 огляду на викладене, слід провести аналогію з подіями, що мали місце протягом Другої світової війни. У ході евакуації критично-важливих підприємств у 1941 році Урядом СРСР були прийняті дієві заходи щодо переміщення у східні райони країни 1523 промислових підприємств, але частина 
підприємств залишилась на окупованій території [30]. Відповідно до історичної довідки [31] у 1943 році німецькі війська зуміли налагодити роботу 85 металообробних, 70 харчових та 16 інших підприємств.

Проведена робота по евакуації підприємств показала важливу роль загальної мобільності підприємств та здатності, у разі необхідності, частково, або повністю, відновити свою роботу 3 найменшою втратою часу, виробничих потужностей, цінних кадрів у сфері науки та технологій. Викладене дає змогу сформулювати фактор впливу - рівень мобільності елементів системи.

Високий рівень мобільності елементів системи дозволяє швидко функціонально відновлюватись після вимушеної зміни середовища функціонування, але прослідковуються логічна необхідність у збереженні функціональної ефективності у зміни середовища функціонування. Тому, безумовно, слід врахувати можливість до збереження функціональної ефективності при зміни середовища функціонування i сформулювати відповідний фактор впливу.

Станом на цей час, логістичне забезпечення включає 22 види забезпечення за відповідними напрямами [32], у тому числі за напрямком матеріально-технічного забезпечення.

На нашу думку, за своїм змістом, логістичне забезпечення $€$ підсистемою нижчого рівня, тому фактори, які здійснюють вплив на підсистему безумовно повинні бути враховані під час ідентифікації факторів системи вищого порядку.

Так, О. Нагорнічевський, досліджуючи питання державного управління у сфері матеріально-технічного забезпечення збройних сил, виділяє ряд чинників (факторів), які на його думку гальмують їі розвиток [33]:

1) недостатність фінансових і матеріальних ресурсів, що виділяються на оборону;

2) недостатність ресурсного забезпечення програм реформування Воєнної організації держави та ОПК України;

3) низький рівень забезпечення ЗС України військовою та спеціальною технікою, озброєнням нового покоління;

4) погіршення стану мобілізаційних резервів;

5) неефективне використання виробничих потужностей з випуску озброєнь, військової, спеціальної техніки та майна;

6) неефективність управління матеріальнотехнічним забезпеченням ЗС України;

7) накопичення застарілої i непотрібної військової техніки, озброєння, вибухових речовин;

8) можливостей служб тилу і технічного забезпечення 3 метою більш повного задоволення матеріально-технічних потреб військ.

Проведений М. Криштановичем аналіз системи матеріального забезпечення персоналу [34], показав, що на зацікавленість проходження служби впливає рівень матеріального та фінансового забезпечення персоналу. Це, не $\epsilon$ новим в ідентифікації мотивації до праці, але цей фактор має місце у впливі на СРЗ СБ і О України, через наявність людської діяльності у функціонуванні системи, тим більше, коли у рамках системи наявні процеси розподілу ресурсів шляхом прийняття рішень людиною.

У монографії щодо системного підходу до оборонного менеджменту [35] автори наголошують на важливості наявності міцних партнерських відносин між складовими сил оборони та оборонною промисловістю України у процесі задоволення потреб оборони. Зазначене дає змогу обґрунтовано виділити наступний фактор впливу на предметну систему - рівень партнерських відносин між складовими сил оборони та оборонною промисловістю України.

У процесі ідентифікації факторів впливу на СРЗ СБ і О України було зосереджено увагу на наявних проблемах пов'язаних із функціонуванням системи та прийняття управлінських рішень на всіх її рівнях. Одним 
із таких питань залишається протидія корупції. Це підтверджується зосередженням значної уваги суб'єктами формування та реалізації державної політики, а також виданням низки нормативно-правових документів, що визначають механізми протидії проявам корупції в Україні: Закону України “Про запобігання корупції” [36] Постанови Кабінету Міністрів України від 05.10.2016 р. № 803-p “Деякі питання запобігання корупції в міністерствах" [37]. У СБ і О України видані відповідні антикорупційні програми та інші документи, що регулюють питання протидії корупції [38-40].

Як приклад, Робочим планом оцінки корупційних ризиків у діяльності МО України [41] передбачені такі об'єкти корупційних ризиків: система внутрішнього контролю, бюджетна діяльність та управління фінансами; управління персоналом; проведення процедур закупівель; управління матеріальними ресурсами, державними підприємствами, установами та організаціями, використання земель оборони; реалізація контрольно-наглядових функцій; забезпечення життєдіяльності 3С України, ефективне управління виділеним ресурсом в зоні Операції об'єднаних Сил.

Гостра проблематика проявів корупції підтверджується високим рівнем корупції в Україні (за підсумками 2020 року Україна займає 117 місце зі 180 країн за індексом сприйняття корупції) [42].

Також, думку про необхідність врахування фактору рівня корупції розділяє $Є$. М. Білоусов, підтверджену у процесі дослідження передумов корупції та економічної безпеки держави. Автор наголошує на визначальному впливі рівня корупції на систему національної безпеки. СРЗ СБ і О є підсистемою системи СБ і О, яка у свою чергу, $€$ підсистемою системи національної безпеки України.

Високий рівень корупції спричинений, у тому числі: низькою ефективністю діяльності контролюючих інституцій у складі СБ і О; відсутністю синхронізації їх діяльності; дублювання функцій; ручним управлінням; низьким рівнем реалізації пропозицій та рекомендацій за результатами контрольних заходів (перевірок); наявна дисциплінарна практика по відношенню до посадових осіб, 3 вини яких допущенні порушення не завжди адекватна рівню порушення.

Вплив корупції на СРЗ СБ і О як систему в якій здійснюється розподіл та освоєння ресурсів $\epsilon$ беззаперечним та повинен бути врахований у аналізі факторів, що здійснюють вплив на ресурсне забезпечення потреб оборони.

У свою чергу, високий рівень корупції при дослідженні реалізації потребує уваги за використанням ресурсів в системі СБіО (реалізація контрольно-наглядових функцій в системі).

У наслідок існуючих ризиків в системі СБіО України поряд 3 корупційними правопорушеннями має місце лобіювання економічних та політичних рішень.

Природа “лобіювання" прийняття рішень у сфері ресурсного забезпечення $\epsilon$ передумовою можливості подальшого виникнення як реального, так і потенційного конфлікту інтересів з вчиненням відповідного корупційного правопорушення.

у своїй праці щодо зовнішнього економічного впливу на економіки деяких країн світу Д. Перкінс [43] наголошує на наявності високого рівня "лобіювання" інтересів приватних компаній та корпорацій задля отримання економічних та інших переваг за рахунок просування та ухвалення необхідних політичних рішень. Автор доводить, що оборонна промисловість США витрачає значний обсяг фінансового ресурсу для лобіювання прийняття відповідних, на свою користь рішень.

Досліджуючи питання взаємозв'язку економіки та війни, В. І. Мірненко, І. М. Ткач та В. Л. Рихтюк визначають, що: “економіка $€$ матеріальним підґрунтям ведення війни, тому, що саме вона впливає на ії масштаби, тривалість і напруження. Для того, щоб вести війни, потрібні збройні сили, а для їх 
створення й утримання потрібні значні кошти. їх кількість, яку може виділити держава, залежить від рівня її економічного розвитку. Чим вищий рівень економічного розвитку держави, тим вище якість озброєння і бойової техніки, а збройні сили матимуть більші бойові можливості" [44].

Зазначене, дає змогу сформулювати фактор впливу - тривалість збройної агресії, або ведення бойових дій. Фактор обумовлений вичерпністю ресурсів та необхідністю відновлювання джерел їх формування.

Повертаючись до результатів наукових праць А. Жомені, слід додати, що при дослідженні проблеми воєнної науки та суспільства дослідник наголошує на тому, що у сучасній війні резерви відіграють значну роль [45-46]. Керівництво держави повинно передбачити відповідні резерви на всіх рівнях забезпечення національної безпеки, як на національному рівні, так і y розпорядженні відповідного військового керівництва. Під резервами, у даному контексті, необхідно розуміти ресурси, що можуть бути використані у кризових ситуаціях за попередньо визначеним пріоритетом. Це підтверджує необхідність врахування фактору впливу - рівень стратегічних резервів держави для забезпечення невідкладних потреб оборони України.

Аналіз стану забезпечення 3С України фінансовими ресурсами та порядку комплексного планування розвитку 3С України, проведений Р. В. Бойко та колективом науковців, ідентифікував групу воєнно-економічних факторів, які безумовно, мають вплив на сферу ресурсного забезпечення СБ іО України: обсяг фінансування ЗС України, номінальний рівень ВВП України; рівень державного боргу, річний індекс інфляції, динаміка індексу промислового виробництва [47].

Також, у своєму дослідженні [48] О. М. Семененко та група авторів наголошують на важливості саме часу, як визначального фактору в процесі прогнозування динаміки розвитку 3С України 3 урахуванням достатності та ефективності освоєння виділених фінансових ресурсів.

Ефективність освоєння виділеного фінансового ресурсу, насамперед, залежить від наявності конфлікту відповідальності між: керівниками, структурними підрозділами, нормативно-правовими актами та розпорядчими документами у сфері ресурсного забезпечення, що підтверджено результатами дослідження [49].

Також, до факторів впливу можна віднести: запаси сировини необхідної для оборонної промисловості, запаси продовольства, спроможність інфраструктури, рівень адаптивності системи ресурсного забезпечення до функціонування в умовах війни (бойових дій), рівень науково-технічного розвитку як елементу воєнно-економічного потенціалу, соціально-економічні умови функціонування системи ресурсного забезпечення, рівень міжнародної підтримки, компетентності та освіта керівників.

У Об'єднаній оперативній концепції сил оборони до 2030 року [50], що $\epsilon$ довгостроковим документом у сфері оборонного планування визначено ряд внутрішніх факторів впливу соціальнополітичного, економічного та іншого характеру на досягнення силами оборони визначених спроможностей. Слід додати, що базовою компонентою спроможності виступає, у тому числі, іï ресурсне забезпечення. Тому, вважається доцільним врахувати ряд факторів негативного впливу на систему ресурсного забезпечення:

1) дефіцит ресурсів для розвитку держави;

2) велика залежність України від імпорту енергоносіїв;

3) поглиблення процесів деіндустріалізації економіки, банкрутство підприємств в критичних для безпеки галузях національної економіки;

4) старіння виробничих фондів;

5) депопуляція населення;

6) загальна тенденція до зниження якості освіти; 
7) загальна тенденція до зниження рівня розвитку науки;

8) зниження рівня готовності населення захищати свою країну зі зброєю в руках;

9) зростання недовіри серед населення України до державної еліти;

10) недостатність системних реформ у сфері національної безпеки і оборони;

11) наявність значної частки тіньової економіки в економіці України, поширення корупції, значний вплив інтересів олігархічних груп на формування і реалізацію державної політики;

12) недосконалість інформаційноаналітичного забезпечення процесів формування і реалізації воєнної політики;

13) системність негативних наслідків у СР3 СБ і О України.

Аналіз документу, у частині визначення пріоритетів та основних напрямів розвитку сил оборони щодо ресурсного забезпечення, дав змогу сформулювати такі фактори впливу:

1) загальні можливості підприємств оборонно-промислового комплексу;

2) рівень відновлення непорушних запасів;

3) рівень спроможностей єдиної системи логістичного забезпечення;

4) захищеність арсеналів, баз, складів;

5) розвиток внутрішнього ринку товарів оборонного призначення;

6) розвиток хімічної та легкої промисловості;

7) безперервне, всебічне забезпечення військ (сил).

На нашу думку, до усіх розглянутих факторів слід додати фактори логічно сформуванні протягом дослідження на основі аналізу джерельної бази використаної у дослідженні:

1) рівень автоматизації процесів ресурсного забезпечення, що пояснюється стрімким науково-технічним прогресом в усіх галузях та сферах людської активності, що безумовно, вимагає швидкої переорієнтації у діяльності, активної імплементації новітніх методів та підходів. На заміну повільного, тривалого переходу між типами зброї що складав десятки років настає ера стрімких перетворень, викликаних розвитком науки і техніки. Це неодмінно вимагає врахування темпу перетворень у військовій справі.

У сучасній збройній боротьбі визначальну перевагу має та сторона, яка за допомогою автоматизації управління, у більшій мірі, може звільнити персонал залучений у головний процес від другорядної механічної праці, а керівників та ключових виконавців від другорядних завдань. Це в повному обсязі (більш ефективно) дасть можливість використати їх розумові, творчі та креативні здібності. Підвищення рівня автоматизації зумовлює підвищення інтелектуальних здібностей персоналу задіяного у відповідних процесах. По-перше персонал повинен володіти необхідним рівнем компетенції, подруге - вивільнений час можна направити саме на розумову роботу.

Крім того, досліджуючи сучасну економічну думку П. Нарижний прийшов до висновку, що за ступенем значущості, в якості головного фактору економічного зростання виступає фактор знання, який включає розвиток технологій, науково-технічного прогресу, науки та інформації;

2) політичне середовище функціонування процесів ресурсного забезпечення;

3) середовище функціонування процесів ресурсного забезпечення.

На додаток, досліджуючи проблематику оборонної достатності України В. М. Замана групує фактори зовнішнього та внутрішнього Впливу на СРЗ СБ і О України [51] наступним чином: внутрішні - політичні, воєнні, економічні, соціокультурні, соціальнопсихологічні, демографічні, духовні, часові, інформаційні; зовнішні - географічні; історичні (цивілізаційні); економічні; політичні; військові; релігійні; етнічні; інформаційні; екологічні тощо.

Узагальнення та обробка ідентифікованих у ході аналізу факторів дає змогу провести їх узагальнення:

- вектор політики держави у сфері оборони 
(зовнішній);

- “лобіювання" прийняття рішень у сфері ресурсного забезпечення (зовнішній);

- банкрутство підприємств в критичних для безпеки галузях національної економіки (зовнішній);

- брак впровадження проривних технологій в оборонну сферу (внутрішній/зовнішній);

- вплив інтересів олігархічних груп на формування і реалізацію державної політики (зовнішній);

- депопуляція населення (зовнішній);

- динаміка індексу промислового виробництва (зовнішній);

- динаміка поширення корупції в країні (зовнішній);

- економічні можливості держави (зовнішній);

- живучість та захищеність об'єктів ресурсного забезпечення (у тому числі, арсеналів, баз, складів (внутрішній);

- запаси продовольства (внутрішній);

- запаси сировини необхідної для оборонної промисловості (зовнішній);

- засоби сполучення в системі ресурсного забезпечення (внутрішній);

- інтелектуальні здібності персоналу (внутрішній);

- інформація як фактор виробництва (внутрішній/зовнішній);

- можливості служб тилу і технічного забезпечення щодо повного задоволення матеріально-технічних потреб військ (внутрішній);

- можливості підприємств обороннопромислового комплексу (зовнішній);

- навколишнє функціонування процесів ресурсного забезпечення (зовнішній);

- наявний порядок розподілу ресурсів (зовнішній/внутрішній);

- номінальний рівень ВВП України (зовнішній);

- обсяг фінансових і матеріальних ресурсів, що виділяються на оборону (зовнішній);

- особистісні здібності лідерів (керівників), професійна компетенція, освіта керівників (внутрішній);

- політичне середовище функціонування процесів ресурсного забезпечення (зовнішній);

- рівень (стан) вітчизняної науки (зовнішній);

- рівень (стан) науково-технічного прогресу (зовнішній);

- рівень автоматизації процесів ресурсного забезпечення (внутрішній);

- рівень адаптивності системи ресурсного забезпечення до функціонування в умовах війни (бойових дій), (внутрішній);

- рівень безперебійності забезпечення військ (сил), (зовнішній/внутрішній);

- рівень відновлення непорушних запасів (зовнішній);

- рівень військових запасів (внутрішній);

- рівень воєнно-економічного потенціалу країни (зовнішній);

- рівень впровадження результатів досліджень та найкращих практик (зовнішній/внутрішній);

- рівень готовності населення захищати свою країну зі зброєю в руках (зовнішній);

- рівень державного боргу (зовнішній);

- рівень економічного шпигунства (зовнішній);

- рівень залежності країни від імпорту енергоносіїв (зовнішній);

- рівень корупції в країні (зовнішній);

- рівень матеріального забезпечення персоналу, задіяного у сфері ресурсного забезпечення (зовнішній);

- рівень міжнародної підтримки (зовнішній);

- рівень мобільності елементів системи (внутрішній);

- рівень накопичення застарілої i непотрібної військової техніки, озброєння, вибухових речовин (внутрішній);

- рівень науково-технічного розвитку як елементу воєнно-економічного потенціалу (зовнішній);

- рівень наявності стратегічних резервів держави (зовнішній); 
- рівень поточного виробництва засобів збройної боротьби (зовнішній);

- рівень розвитку технологій (зовнішній);

- рівень спроможностей єдиної системи логістичного забезпечення (внутрішній);

- рівень тіньової економіки в країні (зовнішній);

- річний індекс інфляції (зовнішній);

- розвиток вітчизняних технологій (зовнішній);

- розвиток внутрішнього ринку товарів оборонного призначення (зовнішній);

- розвиток легкої промисловості держави (зовнішній);

- розвиток машинобудівної промисловості держави (зовнішній);

- розвиток хімічної держави (зовнішній);

- скорочення результативності науководослідних та дослідно-конструкторських робіт внаслідок обмеженого фінансування, скорочення видатків (зовнішній);

- спроможність

(зовнішній);

- стан забезпечення військовою та спеціальною технікою, озброєнням нового покоління (зовнішній);

- стан безперервного, всебічне забезпечення військ (сил) (зовнішній);

- стан використання виробничих потужностей з випуску озброєнь, військової, спеціальної техніки та майна (зовнішній);

- стан виробництва продукції військового призначення (зовнішній);

- стан виробничих потужностей та рівня їх розвитку (внутрішній/зовнішній);

- стан впровадження системних реформ у сфері національної безпеки і оборони (зовнішній);

- стан інвестування в розвиток оборонної промисловості (зовнішній);

- стан інформаційно-аналітичного забезпечення процесів формування і реалізації воєнної політики (зовнішній);

- стан мобілізаційних резервів (зовнішній);

- стан партнерських відносин між складовими сил оборони та оборонною промисловістю України (зовнішній);

- стан поглиблення процесів деіндустріалізації економіки (зовнішній);

- стан ресурсного забезпечення програм реформування воєнної організації держави та ОПК України (зовнішній);

- стан рівня розвитку науки (зовнішній);

- стан управління матеріально-технічним забезпеченням (внутрішній);

- стан якості освіти (зовнішній);

- стан (рівень) реалізації функції щодо контролю за використанням ресурсів в системі сектору безпеки і оборони (реалізація контрольно-наглядових функцій в системі)

- процес старіння виробничих фондів (зовнішній);

- темп технологічних перетворень у військовій справі (зовнішній);

- тривалість збройної агресії, або ведення бойових дій (зовнішній);

- умови функціонування системи ресурсного забезпечення (зовнішній);

- фактор випадковості (невизначеності), (зовнішній);

- фактор віддаленості військових запасів від районів зосередження військ (сил), (внутрішній);

- фактор збереження функціональної ефективності при зміни середовища функціонування (внутрішній);

- фактор наявності конфлікту відповідальності між: керівниками, структурними підрозділами, керівними та розпорядчими документами у сфері ресурсного забезпечення (внутрішній);

- фактор мобільності ресурсів (внутрішній);

- фактор системності негативних наслідків в СРЗ СБ і О України (внутрішній/зовнішній);

- фактор часу (внутрішній/зовнішній);

- цілеспрямований (опосередкований) вплив ворожих сил і засобів як на об'єкти оборонно-промислового комплексу, так і на об'єкти економічного значення та інфраструктури (зовнішній).

Слід нагадати про ідентифікацію низки груп факторів у ході проведеного контентаналізу [52]. Така широка структуризація (26 
груп факторів впливу на систему ресурсного забезпечення) потребує більш широкого узагальнення. Так, вченими було виділено: фінансові, політичні, демографічні, історичні, невизначеності, виробничо-технічні, мобілізаційні, інформаційні, часові, економічні, суб'єктивні, організаційні, людські, технологічні, дестабілізуючі, соціально-психологічні, духовні (релігійні), етнічні, природні, воєнно-економічні фактори тощо.

Найпоширенішими факторами, на які звертали увагу науковці - $є$ групи політичних, економічних, людських, дестабілізуючих та часових факторів (рис. 1).

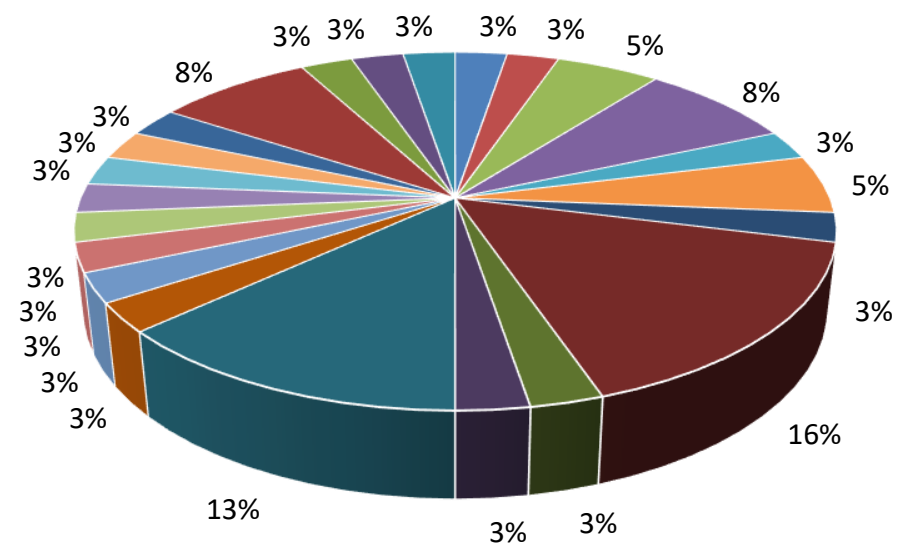

- фінансові
- політичні
- демографічні
- історичні
- невизначеності
- виробничо-технічні
- невизначеності
- мобілізаційні

- мобілізаційні

- інформаційні

- часові

- економічні

- суб'єктні фактори

- організаційні

- людські

- технологічні

\author{
- дестабілізуючі \\ - соц.-псих \\ - духовні (релегійні) \\ - етнічні \\ - природні \\ - стан тилового забезпечення \\ - воєнно-економічні
}

Рисунок 1 - Групи факторів які мають вплив на систему ресурсного забезпечення

Тому, групи факторів отримані у ході проведеного контент-аналізу доцільно розглянути через призму складових PESTаналізу, а саме за напрямом: політичних, економічних, соціально-культурних та технологічних факторів.

PEST-аналіз - це інструмент стратегічного управлінні для визначення напрямку розвитку та розробленні стратегії компанії на довгострокову перспективу, який може бути використаний аналізі факторів цього дослідження.

PEST - $\epsilon$ абревіатурою скорочення заголовних літер, що позначають групи факторів, де P (Politics) - політичні фактори, E
(Economics) - економічні фактори, S (Socioculture) - соціально-культурні фактори, Т (Technology) - технологічні фактори.

Підхід орієнтований на ґрунтовний аналіз факторів зовнішнього середовища, що здійснюють вплив на діяльність об'єкта та у свою чергу $\epsilon$ незалежними від показників функціонування об'єкту [53-54]. Особливістю PEST-аналізу є можливість подивитись зверху на середовище діяльності об'єкта та його місце, так званий "helicopter view" [55].

Однією 3 цілей даного дослідження $€$ ідентифікація якнайбільше факторів для виділення головних з них шляхом експертного оцінювання, тому на даному 
етапі дослідження обмеження щодо факторів зовнішнього впливу не застосовується.

Усі ідентифіковані фактори можна розкласти у межах складових матриці PEST- аналізу та враховуючі специфіку військової справи до переліку складових PEST-аналізу пропонується ввести п'яту складову специфічні фактори (табл. 1).

Таблиця 1 - розподіл факторів впливу на СРЗ СБ і О України за складовими РEST-аналізу

\begin{tabular}{|c|c|c|}
\hline $\begin{array}{c}\text { Категорія } \\
\text { факторів }\end{array}$ & Найменування фактору & Вид фактору впливу \\
\hline \multirow[t]{10}{*}{ Політичні } & 1) реалізація контрольно-наглядових функцій в системі & внутрішній/зовнішній \\
\hline & 2) вектор політики держави у сфері оборони) & зовнішній \\
\hline & $\begin{array}{l}\text { 3) “лобіювання" прийняття рішень у сфері ресурсного } \\
\text { забезпечення }\end{array}$ & внутрішній/зовнішній \\
\hline & $\begin{array}{l}\text { 4) вплив інтересів олігархічних груп на формування і } \\
\text { реалізацію державної політики }\end{array}$ & зовнішній \\
\hline & $\begin{array}{l}\text { 5) політичне середовище функціонування процесів } \\
\text { ресурсного забезпечення }\end{array}$ & зовнішній \\
\hline & 6) рівень міжнародної підтримки & зовнішній \\
\hline & $\begin{array}{l}\text { 7) стан впровадження системних реформ у сфері } \\
\text { національної безпеки і оборони }\end{array}$ & зовнішній \\
\hline & $\begin{array}{l}\text { 8) стан інформаційно-аналітичного забезпечення процесів } \\
\text { формування і реалізації воєнної політики }\end{array}$ & зовнішній \\
\hline & $\begin{array}{l}\text { 9) стан партнерських відносин між складовими сил оборони } \\
\text { та оборонною промисловістю України }\end{array}$ & зовнішній \\
\hline & 10) тривалість збройної агресії, або ведення бойових дій & зовнішній \\
\hline \multirow[t]{21}{*}{ Економічні } & $\begin{array}{l}\text { 11) банкрутство підприємств в критичних для безпеки } \\
\text { галузях національної економіки }\end{array}$ & зовнішній \\
\hline & 12) динаміка індексу промислового виробництва & зовнішній \\
\hline & 13) динаміка поширення корупції в країні & зовнішній \\
\hline & 14) економічні можливості держави & зовнішній \\
\hline & 15) запаси продовольства & внутрішній/зовнішній \\
\hline & $\begin{array}{l}\text { 16) запаси сировини необхідної для оборонної } \\
\text { промисловості }\end{array}$ & зовнішній \\
\hline & 17) інформація як фактор виробництва & внутрішній/зовнішній \\
\hline & $\begin{array}{l}\text { 18) можливості підприємств оборонно-промислового } \\
\text { комплексу }\end{array}$ & зовнішній \\
\hline & 19) наявний порядок розподілу ресурсів & внутрішній/зовнішній \\
\hline & 20) номінальний рівень ВВП України & зовнішній \\
\hline & $\begin{array}{l}\text { 21) обсяг фінансових і матеріальних ресурсів, що } \\
\text { виділяються на оборону }\end{array}$ & зовнішній \\
\hline & 22) рівень безперебійності забезпечення військ (сил) & зовнішній/внутрішній \\
\hline & 23) рівень відновлення непорушних запасів & зовнішній \\
\hline & 24) рівень військових запасів & внутрішній \\
\hline & 25) рівень воєнно-економічного потенціалу країни & зовнішній \\
\hline & 26) рівень державного боргу & зовнішній \\
\hline & 27) рівень економічного шпигунства & зовнішній/внутрішній \\
\hline & 28) рівень залежності країни від імпорту енергоносіїв & зовнішній \\
\hline & 29) рівень корупції в країні & зовнішній \\
\hline & 30) рівень наявності стратегічних резервів держави & зовнішній \\
\hline & $\begin{array}{l}\text { 31) рівень поточного виробництва засобів збройної } \\
\text { боротьби }\end{array}$ & зовнішній \\
\hline
\end{tabular}


ISSN 2522-9842 Journal of Scientific Papers "Social Development and Security", Vol. 11, No. 6, - 2021

\begin{tabular}{|c|c|c|}
\hline $\begin{array}{l}\text { Категорія } \\
\text { факторів }\end{array}$ & Найменування фактору & Вид фактору впливу \\
\hline & 32) рівень тіньової економіки в країні & зовнішній \\
\hline & 33) річний індекс інфляції & зовнішній \\
\hline & $\begin{array}{l}\text { 34) розвиток внутрішнього ринку товарів оборонного } \\
\text { призначення }\end{array}$ & зовнішній \\
\hline & 35) розвиток легкої промисловості держави & зовнішній \\
\hline & 36) розвиток машинобудівної промисловості держави & зовнішній \\
\hline & 37) розвиток хімічної промисловості держави & зовнішній \\
\hline & 38) спроможність інфраструктури & зовнішній \\
\hline & $\begin{array}{l}\text { 39) стан забезпечення військовою та спеціальною } \\
\text { технікою, озброєнням нового покоління }\end{array}$ & зовнішній \\
\hline & 40) стан безперервного, всебічне забезпечення військ (сил) & зовнішній \\
\hline & $\begin{array}{l}\text { 41) стан використання виробничих потужностей з випуску } \\
\text { озброєнь, військової, спеціальної техніки та майна }\end{array}$ & зовнішній \\
\hline & 42) стан виробництва продукції військового призначення & зовнішній \\
\hline & 43) стан виробничих потужностей та рівня їх розвитку & зовнішній \\
\hline & 44) стан інвестування в розвиток оборонної промисловості & зовнішній \\
\hline & 45) стан мобілізаційних резервів & зовнішній \\
\hline & 46) стан поглиблення процесів деіндустріалізації економіки & зовнішній \\
\hline & $\begin{array}{l}\text { 47) стан ресурсного забезпечення програм реформування } \\
\text { воєнної організації держави та ОПК України }\end{array}$ & зовнішній \\
\hline & 48) процес старіння виробничих фондів & зовнішній \\
\hline \multirow{5}{*}{$\begin{array}{l}\text { Соціально- } \\
\text { культурні }\end{array}$} & 49) депопуляція населення & зовнішній \\
\hline & 50) інтелектуальні здібності персоналу & внутрішній \\
\hline & $\begin{array}{l}\text { 51) особистісні здібності лідерів (керівників), професійна } \\
\text { компетенція, освіта керівників }\end{array}$ & внутрішній \\
\hline & $\begin{array}{l}\text { 52) рівень готовності населення захищати свою країну зі } \\
\text { зброєю в руках }\end{array}$ & зовнішній \\
\hline & 53) стан якості освіти & зовнішній \\
\hline \multirow[t]{13}{*}{ Технологічні } & $\begin{array}{l}\text { 54) брак впровадження проривних технологій в оборонну } \\
\text { сферу }\end{array}$ & зовнішній \\
\hline & 55) засоби сполучення в системі ресурсного забезпечення & Внутрішній \\
\hline & 56) рівень (стан) вітчизняної науки & зовнішній \\
\hline & 57) рівень (стан) науково-технічного прогресу & зовнішній \\
\hline & 58) рівень автоматизації процесів ресурсного забезпечення & внутрішній \\
\hline & $\begin{array}{l}\text { 59) рівень впровадження результатів досліджень та } \\
\text { найкращих практик }\end{array}$ & внутрішній \\
\hline & $\begin{array}{l}\text { 60) рівень матеріального забезпечення персоналу, } \\
\text { задіяного у сфері ресурсного забезпечення }\end{array}$ & зовнішній \\
\hline & 61) рівень мобільності елементів системи & внутрішній \\
\hline & $\begin{array}{l}\text { 62) рівень науково-технічного розвитку як елементу воєнно- } \\
\text { економічного потенціалу }\end{array}$ & внутрішній \\
\hline & 63) рівень розвитку технологій & зовнішній \\
\hline & 64) розвиток вітчизняних технологій & зовнішній \\
\hline & $\begin{array}{l}\text { 65) скорочення результативності науково-дослідних та } \\
\text { дослідно-конструкторських робіт внаслідок обмеженого } \\
\text { фінансування, скорочення видатків }\end{array}$ & \\
\hline & 66) темп технологічних перетворень у військовій справі & \\
\hline
\end{tabular}


ISSN 2522-9842 Journal of Scientific Papers "Social Development and Security", Vol. 11, No. 6, - 2021

\begin{tabular}{|c|c|c|}
\hline $\begin{array}{l}\text { Категорія } \\
\text { факторів }\end{array}$ & Найменування фактору & Вид фактору впливу \\
\hline \multirow[t]{16}{*}{$\begin{array}{l}\text { Специфічні } \\
\text { фактори }\end{array}$} & $\begin{array}{l}\text { 67) живучість та захищеність об'єктів ресурсного } \\
\text { забезпечення (у тому числі, арсеналів, баз, складів }\end{array}$ & внутрішній \\
\hline & $\begin{array}{l}\text { 68) можливості служб тилу і технічного забезпечення } \\
\text { щодо повного задоволення матеріально-технічних потреб } \\
\text { військ }\end{array}$ & зовнішній \\
\hline & $\begin{array}{l}\text { 69) навколишнє середовище функціонування процесів } \\
\text { ресурсного забезпечення }\end{array}$ & зовнішній \\
\hline & $\begin{array}{l}\text { 70) рівень адаптивності системи ресурсного забезпечення } \\
\text { до функціонування в умовах війни (бойових дій) }\end{array}$ & внутрішній \\
\hline & $\begin{array}{l}\text { 71) рівень накопичення застарілої і непотрібної військової } \\
\text { техніки, озброєння, вибухових речовин }\end{array}$ & внутрішній \\
\hline & $\begin{array}{l}\text { 72) рівень спроможностей єдиної системи логістичного } \\
\text { забезпечення }\end{array}$ & внутрішній \\
\hline & 73) стан управління матеріально-технічним забезпеченням & внутрішній \\
\hline & $\begin{array}{l}\text { 74) умови функціонування системи ресурсного } \\
\text { забезпечення }\end{array}$ & зовнішній \\
\hline & 75) фактор випадковості (невизначеності) & зовнішній \\
\hline & $\begin{array}{l}\text { 76) фактор віддаленості військових запасів від районів } \\
\text { зосередження військ }\end{array}$ & внутрішній \\
\hline & $\begin{array}{l}\text { 77) фактор збереження функціональної ефективності при } \\
\text { зміни середовища функціонування }\end{array}$ & внутрішній \\
\hline & $\begin{array}{l}\text { 78) фактор наявності конфлікту відповідальності між: } \\
\text { керівниками, структурними підрозділами, керівними та } \\
\text { розпорядчими документами у сфері ресурсного } \\
\text { забезпечення }\end{array}$ & внутрішній \\
\hline & 79) фактор мобільності ресурсів & внутрішній \\
\hline & 80) фактор системності негативних наслідків & зовнішній \\
\hline & 81) фактор часу & зовнішній \\
\hline & $\begin{array}{l}\text { 82) цілеспрямований (опосередкований) вплив ворожих сил } \\
\text { і засобів як на об'єкти оборонно-промислового комплексу } \\
\text { так і на об'єкти економічного значення та інфраструктури }\end{array}$ & зовнішній \\
\hline
\end{tabular}

\section{Висновки}

Основною особливістю функціонування системи ресурсного забезпечення як головного об'єкту дослідження $\epsilon$ багатофакторність об'єкту та постійне зростання інформації, що потребує врахування у ході дослідження.

Аналіз показав наявність широкого кола політичних, економічних, соціальнокультурних, технологічних та специфічних факторів. Загалом було виділено 82 фактори зовнішнього та внутрішнього впливу.

Для реалізації мети подальшого дослідження щодо розроблення сучасної концепції ресурсного забезпечення виникає необхідність у оцінюванні ідентифікованих факторі на предмет їх значущості у впливі на предметну систему, шляхом відповідного ранжування. Це дасть змогу виділити коло факторів впливу з найвищим пріоритетом та у подальшому окремо дослідити передумови їх впливу та відповідні показники.

Виконати завдання пропонується здійснити за допомогою методу експертних оцінок. 


\section{Список використаних джерел}

1. Про рішення Ради національної безпеки і оборони України від 14 вересня 2020 року “Про Стратегію національної безпеки України": Указ Президента України від 14 вересня 2020 року № 392/2020. URL: https://www.president.gov.ua/documents/3 922020-35037 (дата звернення: 14.10.2021).

2. Про рішення Ради національної безпеки і оборони України від 25 березня 2021 року "Про Стратегію воєнної безпеки України": Указ Президента України від 25 березня 2021 № 121/2021 URL: https://www.president.gov.ua/documents/1 212021-37661 здата звернення: 14.10.2021).

3. Дєнежкін М. М. Управління оборонними ресурсами: методичний підхід до визначення потреби в ресурсах на розвиток збройних сил у ході оборонного планування. Наука і техніка Повітряних Сил Збройних України. 2018. № 1(30). С. $123-129$.

4. Фатальчук А. В., Жупінський П. О., Возний, А. Ф. Способи забезпечення матеріальнотехнічними ресурсами потреб Збройних Сил у мирний час та особливий період. Збірник наукових праць Центру воєнностратегічних досліджень Національного університету оборони України імені Івана Черняховського. 2015. № 3. С. 125-129.

5. Сисоєв В. В. Концепція моделювання логістичного управління постачанням сил сектору безпеки і оборони держави. Проблеми економіки. 2015. № 3. С. 342351.

6. Наливайко А. Д., Крикун П. М., ПоляєВ, А. І. Планування ресурсів під час оборонного огляду. Збірник наукових праць Центру воєнно-стратегічних досліджень нУОУ імені Івана Черняховського. 2018. № 2(63). С. 57-62.

7. Бойко Р. В., Бутенко М. П., Гудим В. М. Формування підходів до планування спроможностей військ (сил) з врахуванням ïx ресурсного забезпечення. Збірник наукових праць Центру воєнностратегічних досліджень Національного університету оборони України імені Івана Черняховського. 2017. № 3(50).

8. Сурков О. О. Методика оцінювання ризиків під час аналізу ресурсних можливостей держави щодо задоволення потреб Збройних Сил України. Збірник наукових праць Центру воєнно-стратегічних досліджень нуоу імені Івана Черняховського. 2016. № 1(56). С. 69-74.

9. Замана В. М. Оборонна достатність України як фактор стримування воєнної агресії проти України. Актуальні проблеми воєнної науки. Честь і закон. 2013. № 4 (47). C. 4-9.

10. Loishyn, A., Kivlyuk, V., \& Tkach, I. (2021). Analysis of the development of the theory of military science of logistic support of troops (forces) during the german-soviet war. Journal of Scientific Papers "Social Development and Security», 11(4), 81-102. DOI: 10.33445/sds.2021.11.4.7

11. Loishyn, A., Levchenko, S., Tkach, I., \& Vitalii, G. (2019). Assessment of efficiency indicators of internal control system functioning. Journal of Scientific Papers "Social Development and Security", 9(4), 120-130. DOI: 10.33445/sds.2019.9.4.9

12. Астаф'єв А. І. Про військове мистецтво. СПБ, 1856, с. 169.

13. Словник української мови: в 11 томах. Том 10, 1979. - С. 553.

14. Словник-довідник по технічному регулюванні. - 2-е вид. - М.: РИА “Стандарти та якість", 2007. - 288 с.

15. Дюбанов О.О.Системний підхід до врегулювання проблемних процесів автотехнічного забезпечення Сухопутних військ Збройних Сил України. Збірник наукових праць Центру воєнностратегічних досліджень нуОУ імені Івана Черняховського. 2017. № 3(61). С. 119-125.

16. Бескровний Л. Г., Люшковський М. В., Сот Р. Ш. Руська військово-теоретична думка 
19-20 ст. М.: 1960.

17. Крупнов С. І. Діалектика та воєнна наука. М.: Воєніздат, 1963.

18. Смирнов І. А. Розвиток служби тилу та організація забезпечення Армії та Флоту речовим майном у Великій Вітчизняній війні. Матеріали ювілейної військовонаукової конференції Академії, Тилу та транспорту, присвяченої тридцятиріччю перемоги Радянського народу у Великій Вітчизняній війні. Роль тилу Радянських Збройних Сил у досягненні перемоги у Великій Вітчизняній війні. Під редакцією В. Д. Жуковського. Ленінград : ВАТТ, 1975, 119 c.

19. Философия и военная теория [Текст] / С. А. Тюшкевич ; АН СССР, Ин-т воен. истории МО обороны СССР. - М. : Наука, 1975. -311, [1] с. - Библиогр.: С. 299-309.

20. Тюшкевич С. А. Необхідність та випадковість у війні. М., 1962.

21. Маркс К., Енгельс Ф. Соч., т. 20, С. 171.

22. Методологічні проблеми воєнної теорії та практики. Під ред. Н.Я. Сушко, Т. Р. Кондраткової. М. Воєніздат, 1966, 328 с.

23. Шифман М. С. Війна та економіка. М., Воєніздат, 1964. 208 с.

24. Dix A. Wirtschaftskrieg und Kriegswirtschaft. Berlin, 1920, S. 41.

25. Куренков Г. А. Защита экономической тайны от шпионажа в начале холодной войны (1946 ГОД). Ученые записки Новгородского государственного университета. 2020. №2 (27).

26. Андрощук Г. Економічне шпигунство: зростання масштабів і агресивності: Частина $\quad$ I. $2018 . \quad$ URL: https://cutt.ly/GRyTAXr (дата звернення 14.10.2021).

27. Жакшилыков И. Ж. Экономический шпионаж - вид не добросовестной конкуренции. Международный журнал гуманитарных и естественных наук. 2020. № 7(1).

28. Дюков М. С. Системный подход к управлению ресурсами предприятий легкой промышленности. Инновации $и$ инвестиции. $2011 . \quad$ №3. URL: https://cyberleninka.ru/article/n/sistemnyypodhod-k-upravleniyu-resursami-

predpriyatiy-legkoy-promyshlennosti (дата звернення 14.10.2021).

29. Світова гібридна війна: український фронт : монографія / за заг. Ред. В. П. Горбуліна. Харків : Фоліо, 2017. - 496 с.

30. Шигалін Г. І. Народне господарство СРСР у період Великої вітчизняної війни. Соцекгіз, 1960, с. 48.

31. Історія Великої Вітчизняної війни СРСР 1941-1945, т. 3, стр. 487.

32. Доктрина "Об'єднана логістика": військова керівна публікація військовим організаційним структурам щодо поглядів та основних положень 3 управління оборонними ресурсами ВКП 4-00 (01).01, затверджена Головнокомандувачем Збройних Сил України від 19 вересня 2020 року.

33. Нагорнічевський О. Концептуальні засади державного управління у сфері матеріально-технічного забезпечення збройних сил країни в контексті національної безпеки. Збірник наукових праць "Ефрективність державного управління". 2015. № 42. С. 223-229.

34. Криштанович М. Система матеріального забезпечення персоналу ОВС як важливий фактор вирішення завдань національної безпеки України. Збірник наукових праць. Ефективність державного управління. 2014. № 39. C.152-158.

35. Оборонна реформа: системний підхід до оборонного менеджменту: монографія / А. Павліковський, В. Фролов, Ф. Саганюк та ін.; за заг. ред. д. військ. н. А. Сиротенка. Київ: НУОУ, 2020. 274 с.

36. Про запобігання корупції: Закон України від 14.10.2014 № 1700-VII. Відомості Верховної Ради. 2014. № 49, С. 2056.

37. Деякі питання запобігання корупції в міністерствах: Розпорядження Кабінету Міністрів України від 5.10.2016 р. № 803-р. URL: https://zakon.rada.gov.ua/laws/show/ 803-2016-\%D1\%80\#Text (дата звернення 
14.10.2021).

38. Про затвердження Антикорупційної програми Міністерства внутрішніх справ України на 2020-2022 роки: наказ Міністерства внутрішніх справ України від 31.01.2020 № $84 \quad$ URL: https://zakon.rada.gov.ua/rada/show/v0084 320-20\#Text (дата звернення 14.10.2021).

39. Проєкт Антикорупційної програми Міністерства оборони України на 20222024 року URL: https://www.mil.gov.ua/ diyalnist/zapobigannya-proyavam-korupczii/ (дата звернення 14.10.2021).

40. Про утворення системи роботи з питань запобігання корупції в Міністерстві оборони України та Збройних Силах України: наказ Міністерства Оборони України від 24.11.2015 р. № 646. URL: https://www.mil.gov.ua/diyalnist/zapobigan nya-proyavam-korupczii/ (дата звернення 14.10.2021).

41. Робочий план оцінки корупційних ризиків у діяльності Міністерства оборони України: затверджений першим заступником міністра оборони України від 03.12.2020. URL: https://www.mil.gov.ua/content/ coruption/work_plan_ocinky.pdf (дата звернення 14.10.2021).

42. Індекс сприйняття корупції-2020. Трансперенсі Інтернешнл Україна : вебсайт. URL: http://cpi.ti-ukraine.org/\#/ (дата звернення 12.03.2021).

43. Нові зізнання економічного вбивці / пер. 3 англ. Г. Литвиненко. -Х. : Вид-во «Ранок»: «Фабула», 2019. - 368 с.

44. Воєнна економіка : підручник / за ред. В. І. Мірненка, І. М. Ткача, В. Л. Рихтюка. - К. : HУОУ, 2011. - 332 c.

45. Воєнна наука та суспільство: збірка, М.: Видавництво «Народний Пушкінський фонд». 2009. 416с.

46. Твір генерала від інфантерії, барона Жоміні. Типографія шляхів сполучення. 1840 рік. С.-Петербург.

47. Бойко Р. В., Семененко О. М., Водчиць, О. Г., Добровольський Ю. Б., Абрамов А. П. Аналіз стану забезпечення Збройних Сил
України фінансовими ресурсами та

порядок комплексного планування їх розвитку. Збірник наукових праць Центру воєнно-стратегічних досліджень НУОУ імені Івана Черняховського. 2019. № 1(65). 51-58.

48. Семененко О. М., Васюхно С. І., Бокій В. Г., Бутенко М. П. Методичний підхід до прогнозування динаміки розвитку Збройних Сил України з урахуванням достатності та ефективності освоєння виділених фінансових ресурсів. Збірник наукових праць Центру воєнностратегічних досліджень НУОУ імені Івана Черняховського. 2019. № 3(67). 59-65.

49. Обґрунтування механізмів управління ресурсами: оперативне завдання. Навчально-науковий центр оборонного менеджменту Національного університету оборони України імені Івана Черняховського. 2021.

50. Об'єднана оперативна концепція сил оборони 2030. Затверджена начальником Генерального штабу Збройних Сил України 18.03.2021.

51. Замана В. М. Оборонна достатність України як фактор стримування воєнної агресії проти України. Актуальні проблеми воєнної науки. Честь і закон. 2013. № 4 (47). C. 4-9.

52. Visualization of the problems and categories of the sphere of resourcing of the security and defence sector of Ukraine using the content analysis method. Economic Studies (Ikonomicheski Izsledvania) надано до редакції 02.09.2021.

53. Leyva, M., Hechavarria, J., Batista, N., Alarcon, J. A., \& Gomez, O.). A framework for PEST analysis based on fuzzy decision maps. Revista Espacios. 2018. № 39(16).

54. Shtal T. Methods of analysis of the external environment of business activities / T. Shtal, M. Buriak, G. Ukubassova, Y. Amirbekuly, Z. Toiboldinova, T. Tlegen. Revista Espacios. 2018. Vol. 39 (12). P. 22.

55. Чернова Є. EST-аналіз: що це таке і як його провести У прикладах. Управління 
підприємством. URL: https://upr.ru/

article/pest-analiz-chto-eto-takoe-i-kak-ego- provesti-na-primerah/ (дата звернення

14.10.2021).

\title{
Анализ факторов, влияющих на систему обеспечения безопасности и обороны Украины
}

\author{
Анатолий Лойшин * 1 А \\ * Corresponding author: ${ }^{1}$ доктор философии, старший инспектор Главной инспекции, e-mail: aloishyn@gmail.com, ORCID: 0000-0003-2769-9336 \\ А Главная инспекция Министерства обороны Украины, г. Киев, Украина
}

\begin{abstract}
Аннотация
В данной статье рассматривается проблема идентификации факторов влияния на систему ресурсного обеспечения сектора безопасности и обороны Украины. Обосновывается взгляд что идентификация наибольшего количества факторов даст в дальнейшем возможность четко определить границы исследования, предмет исследования. Прослеживается тенденция к повышенному вниманию к разработке новой концепции ресурсного обеспечения сектора безопасности и обороны Украины среди ученых. Целью статьи является идентификация факторов внешнего и внутреннего воздействия на систему ресурсного обеспечения сектора безопасности и обороны Украины для дальнейшего их анализа в ходе разработки современной концепции ресурсного обеспечения сектора безопасности и обороны Украины. Автор приходит к выводу, что сфера современных трансформаций в сфере безопасности и обороны требует пересмотра существующих механизмов ресурсного обеспечения нужд обороны. Особое внимание в статье уделено анализу существующих научных взглядов по проблематике предметной системы. Автором предложена систематизация идентифицированных факторов влияния на систему ресурсного обеспечения сектора безопасности обороны через призму составляющих PESTанализа, а именно по направлению, политических, экономических, социально-культурных и технологических факторов. Учитывая специфику военного дела в перечень составляющих PEST-анализа предлагается ввести пятую составляющую - специфические факторы. Всего в течение проведенного исследования выделено 82 факторов внешнего и внутреннего влияния на предметную систему исследования. На основе проведенного анализа, идентификации и систематизации факторов влияния установлена необходимость в их дальнейшей оценке и ранжировании, что в дальнейшем позволит исследовать отдельно каждый фактор с высоким приоритетом. Результаты проведенного исследования могут быть полезными для ученых и управленцев, исследующих вопросы ресурсного обеспечения сектора безопасности и обороны Украины.
\end{abstract}

Ключевые слова: ресурсное обеспечение, факторы влияния, сектор безопасности и обороны.

\section{Analysis of factors influencing the system of resourcing of the security and defence sector of Ukraine}

\author{
Anatolii Loishyn *1 A \\ * Corresponding author: ${ }^{1} \mathrm{PhD}$, Senior Inspector of the General Inspectorate, e-mail: aloishyn@gmail.com, ORCID: 0000-0003-2769-9336 \\ A General Inspectorate of the Ministry of Defense of Ukraine, Kyiv, Ukraine
}

\begin{abstract}
This article considers the problem of identifying the factors influencing the system of resource provision of the security and defense sector of Ukraine. The view that identification as the
\end{abstract}


largest number of factors will further allow to clearly define the boundaries of the study, the subject of the study is substantiated. There is a tendency to increase attention to the development of a new concept of resource provision of the security and defense sector of Ukraine among scientists. The purpose of the article is to identify the factors of external and internal influence on the resource provision system of the security and defense sector of Ukraine for further analysis during the development of a modern concept of resource provision of the security and defense sector of Ukraine. The author concludes that the sphere of modern transformations in the field of security and defense requires a revision of the existing mechanisms of resource provision of defense needs. Particular attention in the article is paid to the analysis of existing scientific views on the subject system. The author proposes systematization of identified factors influencing the system of resource provision of the defense sector through the prism of the components of PEST-analysis, namely the direction of political, economic, socio-cultural and technological factors and taking into account the specifics of military affairs. Component - specific factors. In total, during the study, 82 factors of external and internal influence on the subject system of the study were identified. Based on the analysis, identification, and systematization of impact factors, the need for their further assessment and ranking has been established, which will further allow to investigate each factor with high priority. The results of this study can be useful for scientists and managers who study the issues of resource provision of the security and defense sector of Ukraine.

Keywords: resourcing, factors of influence, security and defense sector.

\section{References}

1. Pro rishennya Rady natsional'noyi bezpeky i oborony Ukrayiny vid 14 veresnya 2020 roku "Pro Stratehiyu natsional'noyi bezpeky Ukrayiny" [On the decision of the National Security and Defense Council of Ukraine of September 14, 2020 "On the National Security Strategy of Ukraine"]: Ukaz Prezydenta Ukrayiny vid 14 veresnya 2020 roku № 392/2020. Available from: https://www.president.gov.ua/documents/3 922020-35037.

2. Pro rishennya Rady natsional'noyi bezpeky i oborony Ukrayiny vid 25 bereznya 2021 roku "Pro Stratehiyu voyennoyi bezpeky Ukrayiny" [On the decision of the National Security and Defense Council of Ukraine of March 25, 2021 "On the Strategy of Military Security of Ukraine"]: Ukaz Prezydenta Ukrayiny vid 25 bereznya 2021 № 121/2021. Available from: https://www.president.gov.ua/documents/1 212021-37661.

3. Dyenezhkin M. M. Upravlinnya oboronnymy resursamy: metodychnyy pidkhid do vyznachennya potreby $v$ resursakh na rozvytok zbroynykh syl u khodi oboronnoho planuvannya [Management of defense resources: a methodical approach to determining the need for resources for the development of the armed forces in the course of defense planning]. Nauka i tekhnika Povitryanykh Syl Zbroynykh Ukrayiny. 2018. № 1(30). S. 123-129.

4. Fatal'chuk A. V., Zhupins'kyy P. O., Voznyy, A. F. Sposoby zabezpechennya material'notekhnichnymy resursamy potreb Zbroynykh Syl u myrnyy chas ta osoblyvyy period [Methods of providing material and technical resources for the needs of the Armed Forces in peacetime and special periods]. Zbirnyk naukovykh prats' Tsentru voyennostratehichnykh doslidzhen' Natsional'noho universytetu oborony Ukrayiny imeni Ivana Chernyakhovs'koho. 2015. № 3. S. 125-129.

5. Sysoyev V. V. Kontseptsiya modelyuvannya lohistychnoho upravlinnya postachannyam syl sektoru bezpeky i oborony derzhavy [The concept of modeling the logistics management of the supply of forces of the security and defense sector of the state]. Problemy ekonomiky. 2015. № 3. S. 342-351.

6. Nalyvayko A. D., Krykun P. M., Polyayev, A. I. Planuvannya resursiv pid chas oboronnoho ohlyadu [Resource planning during the defense review]. Zbirnyk naukovykh prats' 
Tsentru voyenno-stratehichnykh doslidzhen' NUOU. 2018. № 2(63). S. 57-62.

7. Boyko, R. V., Butenko, M. P., Hudym, V. M. Formuvannya pidkhodiv do planuvannya spromozhnostey viys'k (syl) z vrakhuvannyam yikh resursnoho zabezpechennya [Formation of approaches to planning the capabilities of troops (forces) taking into account their resource provision]. Zbirnyk naukovykh prats' Tsentru voyenno-stratehichnykh doslidzhen' Natsional'noho universytetu oborony Ukrayiny, 2017. № 3(50).

8. Surkov O. O. Metodyka otsinyuvannya ryzykiv pid chas analizu resursnykh mozhlyvostey derzhavy shchodo zadovolennya potreb Zbroynykh Syl Ukrayiny [Methods of risk assessment during the analysis of resource capabilities of the state to meet the needs of the Armed Forces of Ukraine]. Zbirnyk naukovykh prats' Tsentru voyennostratehichnykh doslidzhen' NUOU. 2016. № 1(56). S. 69-74.

9. Zamana V. M. Oboronna dostatnist' Ukrayiny yak faktor strymuvannya voyennoyi ahresiyi proty Ukrayiny. Aktual'ni problemy voyennoyi nauky [Defense sufficiency of Ukraine as a factor of deterrence of military aggression against Ukraine]. Chest' i zakon. 2013. № 4 (47). S. 4 - 9.

10. Loishyn, A., Kivlyuk, V., \& Tkach, I. (2021). Analysis of the development of the theory of military science of logistic support of troops (forces) during the german-soviet war. Journal of Scientific Papers "Social Development and Security», 11(4), 81-102. DOI: 10.33445/sds.2021.11.4.7

11. Loishyn, A., Levchenko, S., Tkach, I., \& Vitalii, G. (2019). Assessment of efficiency indicators of internal control system functioning. Journal of Scientific Papers "Social Development and Security", 9(4), 120-130. DOI: 10.33445/sds.2019.9.4.9

12. Astaf"yev A. I. Pro viys'kove mystetstvo [About martial arts]. SPB, 1856, s. 169.

13. Slovnyk ukrayins'koyi movy [Dictionary of the Ukrainian language]: $v 11$ tomakh. - Tom 10, 1979. - Stor. 553.
14. Slovnyk-dovidnyk po tekhnichnomu rehulyuvanni [Dictionary-reference book on technical regulation]. - 2-e vyd. - Moscow: RYA "Standarty ta yakist"”, 2007. - $288 \mathrm{~s}$.

15. Dyubanov O. O. Systemnyy pidkhid do vrehulyuvannya problemnykh protsesiv avtotekhnichnoho zabezpechennya Sukhoputnykh viys'k Zbroynykh Syl Ukrayiny [System approach to the settlement of problematic processes of auto technical support of the Land Forces of the Armed Forces of Ukraine]. Zbirnyk naukovykh prats' Tsentru voyenno-stratehichnykh doslidzhen' NUOU. 2017. № 3(61). S. 119-125.

16. Beskrovnyy L. H., Lyushkovs'kyy M. V., Sot R. SH. Rus'ka viys'kovo-teoretychna dumka 1920 st. [Russian military-theoretical thought of 19-20 centuries] Moscow: 1960.

17. Krupnov S. I. Dialektyka ta voyenna nauka [Dialectics and military science]. Moscow: Voyenizdat, 1963.

18. Smyrnov I. A. Rozvytok sluzhby tylu ta orhanizatsiya zabezpechennya Armiyi ta Flotu rechovym maynom u Velykiy Vitchyznyaniy viyni [Development of the rear service and organization of providing the Army and Navy with property in the Great Patriotic War]. Materialy yuvileynoyi viys'kovo-naukovoyi konferentsiyi Akademiyi, Tylu ta transportu, prysvyachenoyi trydtsyatyrichchyu peremohy Radyans'koho narodu u Velykiy Vitchyznyaniy viyni. Rol' tylu Radyans'kykh Zbroynykh Syl u dosyahnenni peremohy u Velykiy Vitchyznyaniy viyni. Pid redaktsiyeyu V. D. Zhukovs'koho. Leninhrad : VATT, 1975, $119 \mathrm{~s}$.

19. Filosofiya i voyennaya teoriya [Tekst] [Philosophy and military theory [Text]]/ S. A. Tyushkevich; AN SSSR, In-t voyen. istorii MO oborony SSSR. Moscow: Nauka, 1975. 311 s.

20. Tyushkevych S. A. Neobkhidnist' ta vypadkovist' u viyni [Necessity and chance in war]. Moscow, 1962.21. K. Marx and F. Engels. Soch., Vol. 20, s. 171.

22. Metodolohichni problemy voyennoyi teoriyi ta praktyky [Methodological problems of 
military theory and practice]. Pid red. N.YA. Sushko, T. R. Kondratkovoyi. M. Voyenizdat, 1966, $328 \mathrm{~s}$.

23. Shyfman M. S. Viyna ta ekonomika [War and economy]. Moscow, Voyenizdat, 1964. $208 \mathrm{~s}$.

24. Dix A. Wirtschaftskrieg und Kriegswirtschaft. Berlin, 1920, S. 41.

25. Kurenkov G. A. Zashchita ekonomicheskoy tayny ot shpionazha $v$ nachale kholodnoy voyny (1946 GOD) [Protection of economic secrets from espionage at the beginning of the Cold War (1946)]. Uchenyye zapiski Novgorodskogo gosudarstvennogo universiteta. 2020. № 2 (27).

26. Androshchuk H. Ekonomichne shpyhunstvo: zrostannya masshtabiv i ahresyvnosti: Chastyna I [Economic espionage: growth of scale and aggression: Part I]. 2018. Available from: https://cutt.ly/GRyTAXr (data zvernennya 14.10.2021).

27. Zhakshilykov I. ZH. Ekonomicheskiy shpionazh - vid ne dobrosovestnoy konkurentsii [Economic espionage - a kind of unfair competition]. Mezhdunarodnyy zhurnal gumanitarnykh i yestestvennykh nauk. 2020. № 7(1).

28. Dyukov M. S. Sistemnyy podkhod k upravleniyu resursami predpriyatiy legkoy promyshlennosti [System approach to resource management of light industry enterprises] // Innovatsii i investitsii. 2011. №3. Available from: https://cyberleninka.ru/article/n/sistemnyypodhod-k-upravleniyu-resursami-

predpriyatiy-legkoy-promyshlennosti (data zvernennya 14.10.2021).

29. Svitova hibrydna viyna: ukrayins'kyy front [World hybrid war: Ukrainian front: monograph] : monohrafiya / za zah. Red. V. P. Horbulina. Kharkiv : Folio, 2017. 496 s.

30. Shyhalin H. I. Narodne hospodarstvo SRSR u period Velykoyi vitchyznyanoyi viyny [The national economy of the USSR during the Great Patriotic War]. Sotsek·hiz, 1960, s. 48.

31. Istoriya Velykoyi Vitchyznyanoyi viyny SRSR 1941-1945 [History of the Great Patriotic War of the USSR 1941-1945], t. 3, s. 487.
32. Doktryna "Ob"yednana lohistyka" [Doctrine "United Logistics"]: viys'kova kerivna publikatsiya viys'kovym orhanizatsiynym strukturam shchodo pohlyadiv ta osnovnykh polozhen' z upravlinnya oboronnymy resursamy VKP 4-00 (01).01, zatverdzhena Holovnokomanduvachem Zbroynykh Syl Ukrayiny vid 19 veresnya 2020 roku.

33. Nahornichevs'kyy O. Kontseptual'ni zasady derzhavnoho upravlinnya u sferi material'notekhnichnoho zabezpechennya zbroynykh syl krayiny $v$ konteksti natsional'noyi bezpeky [Conceptual principles of public administration in the field of logistics of the country's armed forces in the context of national security]. Zbirnyk naukovykh prats' "Efektyvnist' derzhavnoho upravlinnya". 2015. № 42. S. 223-229.

34. Kryshtanovych M. Systema material'noho zabezpechennya personalu OVS yak vazhlyvyy faktor vyrishennya zavdan' natsional'noyi bezpeky Ukrayiny [The system of material support of police personnel as an important factor in solving the problems of national security of Ukraine]. Zbirnyk naukovykh prats'. Efektyvnist' derzhavnoho upravlinnya. 2014. № 39. S.152-158.

35. Oboronna reforma: systemnyy pidkhid do oboronnoho menedzhmentu: monohrafiya [Defense reform: a systematic approach to defense management: a monograph]/ A. Pavlikovs'kyy, V. Frolov, F. Sahanyuk ta in.; za zah. red. d. viys'k. n. A. Syrotenka. Kyiv: NUOU, 2020. $274 \mathrm{~s}$.

36. Pro zapobihannya koruptsiyi [On the prevention of corruption]: Zakon Ukrayiny vid 14.10.2014 № 1700-VII. Vidomosti Verkhovnoyi Rady. 2014. № 49, S. 2056.

37. Deyaki pytannya zapobihannya koruptsiyi v ministerstvakh [Some issues of prevention of corruption in the ministries]: Rozporyadzhennya Kabinetu Ministriv Ukrayiny vid 5.10.2016 r. № 803-r. Available from: https://zakon.rada.gov.ua/laws/show/ 803-2016-\%D1\%80\#Text (data zvernennya 14.10.2021).

38. Pro zatverdzhennya Antykoruptsiynoyi 
prohramy Ministerstva vnutrishnikh sprav Ukrayiny na 2020-2022 roky [About the statement of the Anti-corruption program of the Ministry of Internal Affairs of Ukraine for 2020-2022]: nakaz Ministerstva vnutrishnikh sprav Ukrayiny vid 31.01.2020 № 84 Available from: https://zakon.rada.gov.ua/ rada/show/v0084320-20\#Text (data zvernennya 14.10.2021).

39. Proyekt Antykoruptsiynoyi prohramy Ministerstva oborony Ukrayiny na 2022-2024 roku [Draft Anti-Corruption Program of the Ministry of Defense of Ukraine for 20222024]. Available from: https://www.mil.gov.ua/diyalnist/zapobigan nya-proyavam-korupczii/ (data zvernennya 14.10.2021).

40. Pro utvorennya systemy roboty z pytan' zapobihannya koruptsiyi $v$ Ministerstvi oborony Ukrayiny ta Zbroynykh Sylakh Ukrayiny [On the establishment of a system of work on the prevention of corruption in the Ministry of Defense of Ukraine and the Armed Forces of Ukraine]: nakaz Ministerstva Oborony Ukrayiny vid 24.11.2015 r. № 646. Available

from: https://www.mil.gov.ua/diyalnist/zapobigan nya-proyavam-korupczii/ (data zvernennya 14.10.2021).

41. Robochyy plan otsinky koruptsiynykh ryzykiv u diyal'nosti Ministerstva oborony Ukrayiny [Work plan for assessing corruption risks in the activities of the Ministry of Defense of Ukraine]: zatverdzhenyy pershym zastupnykom ministra oborony Ukrayiny vid 03.12.2020. Available from: https://www.mil.gov.ua/content/coruption/ work_plan_ocinky.pdf (data zvernennya 14.10.2021).

42. Indeks spryynyattya koruptsiyi-2020 [Corruption Perceptions Index 2020]. Transperensi Interneshnl Ukrayina : veb-sayt. Available from: http://cpi.ti-ukraine.org/\#/ (data zvernennya 12.03.2021).

43. Novi ziznannya ekonomichnoho vbyvtsi [New confessions of an economic killer]/ per. $z$ anhl. H. Lytvynenko. Kharkiv: Vyd-vo
«Ranok» : «Fabula», 2019. - $368 \mathrm{~s}$.

44. Voyenna ekonomika [Military economics: a textbook]: pidruchnyk / za red. V. I. Mirnenka, I. M. Tkacha, V. L. Rykhtyuka. Kyiv: NUOU, 2011. $332 \mathrm{s.}$

45. Voyenna nauka ta suspil'stvo [Military science and society]: zbirka, Moscow: Vydavnytstvo «Narodnyy Pushkins'kyy fond». 2009. $416 \mathrm{~s}$.

46. Tvir henerala vid infanteriyi, barona Zhomini [The work of the general from the infantry, Baron Jomini]. Typohrafiya shlyakhiv spoluchennya. 1840 rik. S.-Peterburh.

47. Boyko R. V., Semenenko O. M., Vodchyts', O. H., Dobrovol's'kyy YU. B., Abramov A. P. Analiz stanu zabezpechennya Zbroynykh Syl Ukrayiny finansovymy resursamy ta poryadok kompleksnoho planuvannya yikh rozvytku [Analysis of the state of providing the Armed Forces of Ukraine with financial resources and the order of complex planning of their development]. Zbirnyk naukovykh prats' Tsentru voyenno-stratehichnykh doslidzhen' NUOU. 2019. № 1(65). 51-58.

48. Semenenko O. M., Vasyukhno S. I., Bokiy V. H., Butenko M. P. Metodychnyy pidkhid do prohnozuvannya dynamiky rozvytku Zbroynykh Syl Ukrayiny z urakhuvannyam dostatnosti ta efektyvnosti osvoyennya vydilenykh finansovykh resursiv [Methodical approach to forecasting the dynamics of development of the Armed Forces of Ukraine taking into account the adequacy and efficiency of the development of allocated financial resources]. Zbirnyk naukovykh prats' Tsentru voyenno-stratehichnykh doslidzhen' NUOU. 2019. № 3(67). 59-65.

49. Obgruntuvannya mekhanizmiv upravlinnya resursamy: operatyvne zavdannya [Substantiation of resource management mechanisms: operational task]. Navchal'nonaukovyy tsentr oboronnoho menedzhmentu Natsional'noho universytetu oborony Ukrayiny. 2021.

50. Ob"yednana operatyvna kontseptsiya syl oborony 2030 [Joint Operational Concept of the Defense Forces 2030]. Zatverdzhena 
nachal'nykom Heneral'noho shtabu Zbroynykh Syl Ukrayiny 18.03.2021.

51. Zamana V.M. Oboronna dostatnist' Ukrayiny yak faktor strymuvannya voyennoyi ahresiyi proty Ukrayiny. Aktual'ni problemy voyennoyi nauky [Ukraine's defense adequacy as a factor in deterring military aggression against Ukraine]. Chest' i zakon. 2013. № 4 (47). S. 4-9.

52. Visualization of the problems and categories of the sphere of resourcing of the security and defence sector of Ukraine using the content analysis method. Economic Studies (Ikonomicheski Izsledvania).

53. Leyva, M., Hechavarria, J., Batista, N.,
Alarcon, J. A., \& Gomez, O.). A framework for PEST analysis based on fuzzy decision maps. Revista Espacios. 2018. № 39(16).

54. Shtal T. Methods of analysis of the external environment of business activities / T. Shtal, M. Buriak, G. Ukubassova, Y. Amirbekuly, Z. Toiboldinova, T. Tlegen // Revista Espacios. 2018. Vol. 39 (12). P. 22.

55. Chernova YE. PEST-analiz: shcho tse take $i$ yak yoho provesty u prykladakh. Upravlinnya pidpryyemstvom [PEST-analysis: what it is and how to conduct it in examples]. Available from: https://upr.ru/article/pest-analiz-chtoeto-takoe-i-kak-ego-provesti-na-primerah/ (data zvernennya 14.10.2021). 